Original Article

\title{
Spectral analysis and Antibacterial activity of the bioactive principles of Sargassum tenerrimum J. Agardh collected from the Red sea, Jazan, Kingdom of Saudi Arabia
}

\author{
Análise espectral e atividade antibacteriana dos princípios bioativos de Sargassum \\ tenerrimum J. Agardh coletados no mar Vermelho, Jazan, Reino da Arábia Saudita
}

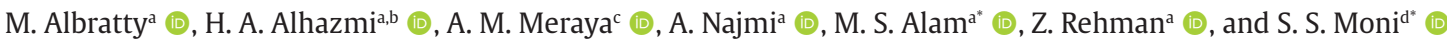 \\ aJazan University, College of Pharmacy, Department of Pharmaceutical Chemistry, Jazan, Saudi Arabia \\ bJazan University, Substance Abuse and Toxicology Research Centre, Jazan, Saudi Arabia \\ Jazan University, College of Pharmacy, Department of Clinical Pharmacy, Jazan, Saudi Arabia \\ dJazan University, College of Pharmacy, Department of Pharmaceutics, Jazan, Saudi Arabia
}

\begin{abstract}
Seaweeds are a major marine resource that can be explored to develop novel pharmaceutical molecules. The present study showed the presence of unique bioactive components in the petroleum ether extract (PEE) and methanolic extract (ME) of Sargassum tenerrimum. The gas chromatography-mass spectrometry analysis suggested that the PEE of S. tenerrimum contained antibacterial biomolecules: hexadecanoic acid, methyl ester, 17-pentatriacontene, dasycarpidan-1-methanol, and acetate (ester). However, the ME of S. tenerrimum exhibited better antibacterial effect than the PEE due to the presence of the bioactive compounds 1,2-benzenedicarboxylic acid, diisooctyl ester, tetratetracontane, 1-docosene, 1,2-benzenediol, and benzoic acid. Thus, promising antibacterial molecules can be isolated from $S$. tenerrimum for better therapeutic use.
\end{abstract}

Keywords: brown alga, Sargassum tenerrimum, bioactive constituents, antibacterial effect.

\begin{abstract}
Resumo
As algas marinhas são um importante recurso marinho que pode ser explorado para desenvolver novas moléculas farmacêuticas. O presente estudo mostrou a presença de componentes bioativos únicos no extrato etéreo de petróleo (PEE) e no extrato metanólico (ME) de Sargassum tenerrimum. A análise por cromatografia gasosaespectrometria de massa sugeriu que o PEE de S. tenerrimum continha biomoléculas antibacterianas: ácido hexadecanoico, éster metílico, 17-pentatriaconteno, dasycarpidan-1-metanol e acetato (éster). Entretanto, o ME de $S$. tenerrimum exibiu melhor efeito antibacteriano do que o PEE devido à presença dos compostos bioativos ácido 1,2-benzenodicarboxílico, éster diisooctil, tetratetracontano, 1-docosene, 1,2-benzoenodiol e ácido benzoico. Assim, moléculas antibacterianas promissoras podem ser isoladas de S. tenerrimum para melhor uso terapêutico.
\end{abstract}

Palavras-chave: alga marrom, Sargassum tenerrimum, constituintes bioativos, efeito antibacteriano.

\section{Introduction}

The pharmaceutical importance of seaweeds has been gaining attention in recent years among various researchers globally (Salehi et al., 2019; Maria et al., 2016). Seaweeds constitute a significant resource from which secondary metabolites can be isolated; those that have specific pharmaceutical properties (Namvar et al., 2014; Bhutiya et al., 2018). Sargassum tenerrimum J. Agardh belonging to the Sargassaceae family, commonly found in the Red Sea, Jazan province, Jazan, Kingdom of Saudi Arabia (KSA), can be studied to develop novel pharmaceutical molecules. To the best of our knowledge, there are very few scientific publications on the pharmaceutical value of S. tenerrimum. Previous studies show that resistance to antibacterial agents is mainly exhibited by Staphylococcus aureus, Streptococcus pyogenes, Mycobacterium tuberculosis, Escherichia coli, and Pseudomonas aeruginosa (Pelgrift and Friedman, 2013; Riley et al., 2012). Recently, a study reported that the methanolic extract of $S$. tenerrimum contains steroids, saponins, alkaloids, tannins, flavonoids, terpenoids proteins, and phenolic compounds (Kumar et al., 2012). In continuation of our earlier works (Moni et al., 2019; Moni et al., 2018), the present study was designed to characterize the bioactive principles found in S. tenerrimum using gas chromatography-mass spectrometry (GC-MS)

*e-mail: wshams.alam@gmail.com; mosalam@jazanu.edu.sa; drsmsivakumar@gmail.com; smoni@jazanu.edu.sa Received: March 7, 2021 - Accepted: June 10, 2021 
and Fourier-transform infrared (FT-IR) techniques. We also evaluated the antibacterial effect of the extracts in vitro against both gram-positive and gram-negative bacteria.

\section{Material and Methods}

\subsection{Chemicals and reagents}

All chemicals and solvents used in this study were purchased from Sigma Aldrich (USA), and supplied by Bayouni Trading Co (Jeddah, KSA). Bacteriological media were products of Scharlau supplied by Somatco (Jeddah, KSA).

\subsection{Study area, collection, and identification}

Jazan, which is a coastal region along the Red Sea, is located in the southwest part of Saudi Arabia and is rich in varieties of seaweeds, especially brown algae. S. tenerrimum is abundantly available in the Red Sea. The seaweed was collected from Al Murjan beach in Jazan, Saudi Arabia, in November 2019. The Al Murjan beach is located 10 kilometers from the city, and the seaweed was harvested by going 10 to 20 meters within the sea from the beach's coastline. Figure 1 representing the study area of Al Murjan beach, Jazan. The collected alga was thoroughly washed twice in seawater at the seashore and exposed to open air to drain the water. The seaweeds were packed in polythene biohazard yellow bags, tied and then transported to the laboratory. The seaweeds were again thoroughly washed under normal tap water to remove adhered impurities. Thereafter, the washed seaweed was air-dried in a well-ventilated room for 15 days. The seaweed was authenticated by Dr. Remesh Moochikkal, herbarium curator, Jazan University herbarium (JAZUH), on depositing a voucher specimen; the identification reference number was JAZUH 1631. The air-dried S. tenerrimum was cut into small pieces and finely powdered using a grinder to obtain a coarse powder. The powdered samples were pooled and packed in an airtight container for further experimental use.

\subsection{Organic solvent extraction}

Hot continuous percolation by Soxhlet apparatus was used to extract active principles from S. tenerrimum using petroleum ether and methanol, separately, at $60{ }^{\circ} \mathrm{C}$ for $4 \mathrm{~h}$. After cooling, the extracts were transferred to glass beakers and air-dried. The dried extracts were subjected to GC-MS and FT-IR spectral analysis to determine the various bioactive compounds present.

\subsection{GC-MS analysis}

GC-MS analysis of the organic solvent extracts of $S$. tenerrimum was performed using a Thermo Scientific GC-MS with the AS 3000 autosampler and ISQ detector. Capillary TR-5MS column ( $30 \mathrm{~m} \times 0.25 \mathrm{~mm}$ ID $\times 0.25 \mu \mathrm{m}$ ) and helium carrier gas at a flow rate of $1.2 \mathrm{~mL} / \mathrm{min}$ was used to achieve the separation of components. Petroleum ether and methanolic extracts were diluted ten times with

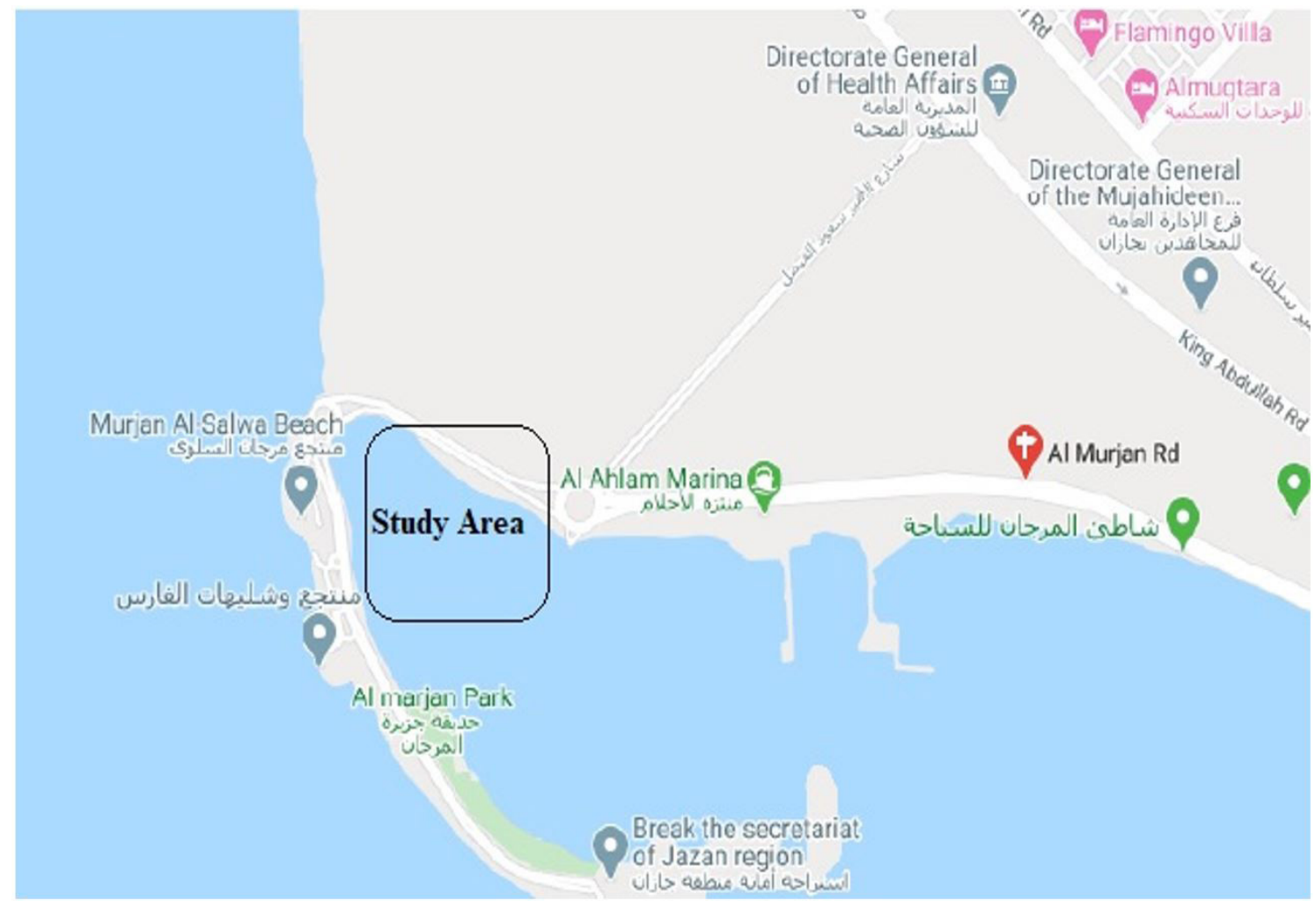

Figure 1. The map of study area of Al Murjan beach, Jazan. 
their respective extraction solvents, soicated, and filtered through $0.45 \mu \mathrm{m}$ filter and injected using splitless mode $(2 \mu \mathrm{L})$. The oven temperature was set initially at $70^{\circ} \mathrm{C}$ and hold for $5 \mathrm{~min}$, subsequently ramped to $205^{\circ} \mathrm{C}, 280^{\circ} \mathrm{C}$, $290^{\circ} \mathrm{C}$ and $300^{\circ} \mathrm{C}$ at a rate of $5^{\circ} \mathrm{C} / \mathrm{min}$ with a holding time of $5 \mathrm{~min}$ at each ramp. The injection port, ion source and MS line transfer temperatures were set at $290^{\circ} \mathrm{C}, 320^{\circ} \mathrm{C}$ and $340^{\circ} \mathrm{C}$ respectively with helium gas flow rate of $1.2 \mathrm{~mL} / \mathrm{min}$ and spectra were recorded using positive ion mode within the mass range of 60-900 amu with delay time of 5 minutes. Structural interpretation of the mass spectrum of the bioactive compounds was carried out using the built-in NIST, Mainlib, and Replib software libraries. The percentage areas of each peak were obtained using Xcalibur software and are uncorrected. The compounds were identified by using match and reverse match factor thresholds of nine hundred and above between measured and standard library spectrum. The identified compounds were further confirmed by their retention indices data obtained by running the mixture of n-alkanes $\left(\mathrm{C}_{6}-\mathrm{C}_{40}\right)$ and comparing with the standard literature values. (Ardrey and Moffat, 1981)

\subsection{Fourier transform infrared spectroscopy studies (FT- IR)}

The functional groups of the organic solvent extracts of S. tenerrimum were elucidated using a Nicolet iS10 FTIR spectrophotometer. Sample was prepared using the $\mathrm{KBr}$ pellet technique, and the spectra were obtained by scanning through the range $4000-400 \mathrm{~cm}^{-1}$, with a resolution of $4 \mathrm{~cm}^{-1}$.

\subsection{Antibacterial analyses}

Human pathogenic bacteria Staphylococcus aureus, Streptococcus pyogenes, Bacillus subtilis, Escherichia coli, Klebsiella pneumoniae, and Pseudomonas aeruginosa were used in this study. The stock was sub-cultured in nutrient broth and incubated at $37{ }^{\circ} \mathrm{C}$ for $24 \mathrm{~h}$ and designated as the $24 \mathrm{~h}$ working culture (WC). The WC was standardized by calculating the colony-forming unit per $\mathrm{ml}$ (CFU/ml) as described by Cappuccino and Sherman, 2014. Standardized cultures were utilized for antibacterial spectral studies. The agar-well diffusion technique was used to determine the activity of both, the methanolic and petroleum ether, extracts of $S$. tenerrimum on aseptically prepared Mueller-Hinton ( $\mathrm{MH}$ ) agar plates. The activity of both the methanolic and petroleum ether extracts of S. tenerrimum was determined by arranging individual sets. After uniformly spreading the standardized cultures $(100 \mu l)$ on individual $\mathrm{MH}$ agar plates, the plates were placed under laminar airflow for $30 \mathrm{~min}$ to allow for diffusion. Wells of $10 \mathrm{~mm}$ diameter were made on the $\mathrm{MH}$ agar plates using a sterilized standard borer. The extracts were then placed in the corresponding wells, and the plates were ideally positioned for the initial diffusion and incubated at $37^{\circ} \mathrm{C}$ for $24 \mathrm{~h}$. The antibacterial activity was determined by measuring the zone of inhibition around the well; the values were expressed in millimeters ( $\mathrm{mm}$ ). The Kirby Bauer technique was used to determine the antibacterial potential of a standard streptomycin disc ( $10 \mu \mathrm{g} /$ disc) (Cappuccino,
Sherman, 2014; John et al., 2018). The antibacterial activity was assessed after the $24 \mathrm{~h}$ incubation by measuring the diameter of inhibitory zones around the wells. The level of activity and potency is directly proportional to the diameter of the zones of inhibition.

\subsection{Statistical analysis}

Statistical analyses were performed using the Graph Pad Instat software system, version 3.10. All the experiments were performed six times $(n=6)$, and the values were represented with a standard deviation. Values of $\mathrm{p}<0.001$, were highly significant. The test values were compared with the standard drug values using Dunnett's post hoc test.

\section{Results and Discussion}

The Red Sea of Jazan, KSA, is rich in many taxonomically diverse seaweeds, especially brown algae. Here, we studied S. tenerrimum, a brown alga, for the presence of bioactive constituents through organic solvent extraction.

\subsection{GC-MS analysis}

Figure 2 shows the bioactive compounds of the PEE of $S$. tenerrimum determined by GC-MS analysis. Their corresponding names, molecular formulae, retention times, retention index, and molecular weights are listed in Table 1. Our results suggested the presence of the following compounds, benzoic acid, 3,5-dicyclohexyl-4-hydroxyester, and a unique methyl ester, called methyl 3,5-dicyclohexyl4-hydroxybenzoate, having a retention time of $63.37 \mathrm{~min}$. A similar compound has been reported in the methanolic extract of Buchholzia Coriacea Engler with a retention time of 48.65 min (Chukwunonye et al., 2015). This compound has not yet been reported in seaweeds and its biological properties have not been published. Isomethadone was identified at $44.11 \mathrm{~min}$ with lesser probability. Cholesterol was another unique molecule observed in the PEE of $S$. tenerrimum. The presence of cholesterol has been reported in the ethyl acetate extract of the marine alga $S$. oligocystum collected from the Persian Gulf (Permeh et al., 2012). Squalene, a triterpene which is an intermediate produced during cholesterol biosynthesis was observed at 50.26 min. Megha et al. (2016) reported that the methanolic extract of $U$. lactuca and L. obtusa contained squalene. An earlier review suggested the cosmetic use of squalene (Huang et al., 2009) and another use as a vaccine adjuvant, especially in the influenza vaccine adjuvant known as MF 59 (Giuseppe et al., 2006). It also possesses anti-cancer properties and reduces blood LDL and cholesterol levels (Lozano-Grande et al., 2018).

Octatriacontyl pentafluoropropionate was detected in the PEE of $S$. tenerrimum at a retention time of $52.42 \mathrm{~min}$ with the highest molecular weight of 696. Recently, this compound was reported in the GC-MS analysis of the methanolic extract of Dendrobium moniliforme with a retention time of $13.036 \mathrm{~min}$ (Paudel et al., 2018). Seaweeds are rich sources of polyunsaturated fatty acids (Moni et al., 2019). The hexadecanoic acid derivative, 9-hexadecenoic acid, eicosyl ester, (Z)-, otherwise 
<smiles>CC[C@H](C)c1cc(C2CCCCC2)c(O)c(C2CCCCC2)c1</smiles>

1

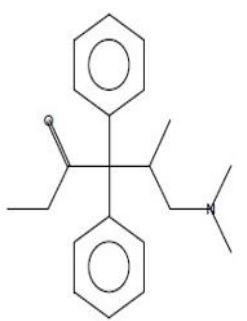

2

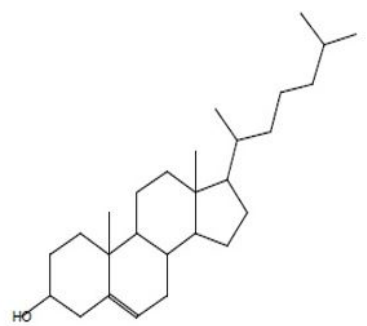

3

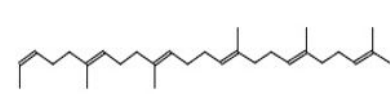

4

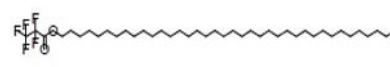

5

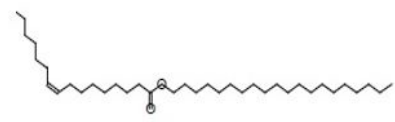

6

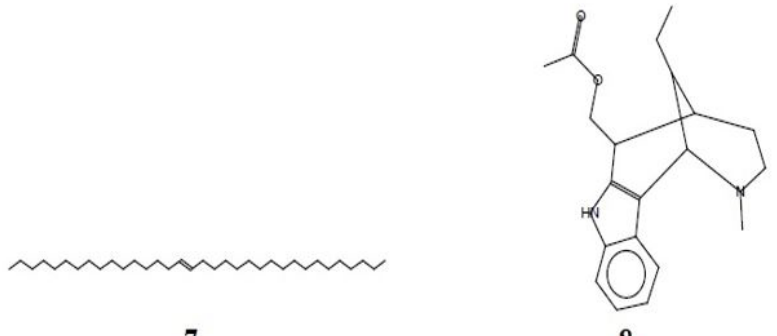

8

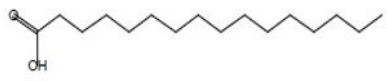

9

Figure 2. Bioactive compounds of petroleum ether extracts of Sargassum tenerrimum was identified through by GC-MS analysis. (1) Benzoic acid, 3,5- dicyclohexyl-4-hydroxy-methyl ester (2) Isomethadone (3) Cholesterol (4) Squalene (5) Octatriacontyl pentafluoropropionate (6) 9-Hexadecenoic acid, eicosyl ester, (Z)-, (7) 17-Pentatriacontene (8) Dasycarpidan-1-methanol, acetate (ester) (9) Hexadecanoic acid, methyl ester.

Table 1. Bioactive compounds of petroleum ether extracts of Sargassum tenerrimum identified through by GC-MS analysis.

\begin{tabular}{|c|c|c|c|c|c|}
\hline S.no & Bioactive compound & $\begin{array}{l}\text { Molecular } \\
\text { formula }\end{array}$ & $\begin{array}{l}\text { Retention time } \\
\text { (Minutes) }\end{array}$ & Molecular weight & Retention Index \\
\hline 1 & $\begin{array}{l}\text { Benzoic acid, } \\
\text { 3,5-dicyclohexyl-4- } \\
\text { hydroxy-, methyl ester }\end{array}$ & $\mathrm{C}_{20} \mathrm{H}_{28} \mathrm{O}_{3}$ & 63.37 & 316 & 2613 \\
\hline 2 & Isomethadone & $\mathrm{C}_{21} \mathrm{H}_{27} \mathrm{NO}$ & 44.11 & 309 & 2110 \\
\hline 3 & Cholesterol & $\mathrm{C}_{27} \mathrm{H}_{46} \mathrm{O}$ & 49.63 & 386 & 2999 \\
\hline 4 & Squalene & $\mathrm{C}_{30} \mathrm{H}_{50}$ & 50.26 & 410 & 2806 \\
\hline 5 & $\begin{array}{l}\text { Octatriacontyl } \\
\text { pentafluoropropionate }\end{array}$ & $\mathrm{C}_{41} \mathrm{H}_{77} \mathrm{~F}_{5} \mathrm{O}_{2}$ & 52.42 & 696 & Unconfirmed \\
\hline 6 & $\begin{array}{l}\text { 9-Hexadecenoic acid, } \\
\text { eicosyl ester, (Z)- }\end{array}$ & $\mathrm{C}_{36} \mathrm{H}_{70} \mathrm{O}_{2}$ & 56.74 & 534 & 3763 \\
\hline 7 & 17-Pentatriacontene & $\mathrm{C}_{35} \mathrm{H}_{70}$ & 70.55 & 490 & 3501 \\
\hline 8 & $\begin{array}{l}\text { Dasycarpidan-1- } \\
\text { methanol, acetate } \\
\text { (ester) }\end{array}$ & $\mathrm{C}_{20} \mathrm{H}_{26} \mathrm{~N}_{2} \mathrm{O}_{2}$ & 70.92 & 326 & 2446 \\
\hline 9 & $\begin{array}{l}\text { Hexadecanoic acid, } \\
\text { methyl ester }\end{array}$ & $\mathrm{C}_{16} \mathrm{H}_{32} \mathrm{O}_{2}$ & 31.81 & 256 & 1925 \\
\hline
\end{tabular}


called methyl palmitoleate was detected in the PEE of $S$. tenerrimum. An earlier report showed that this compound has anti-inflammatory properties (Astudillo et al., 2018). A previous study showed that hexadecanoic acid, the major fatty acid in Sargassum granuliferum, prevents the growth of biofilm-forming bacteria (Bakar et al., 2017). The present study demonstrated that the PEE of S. tenerrimum contains 17-pentatriacontene, which has been reported to have anti-inflammatory, anticancer, antibacterial, and antiarthritic properties (Dinesh et al., 2018). Dasycarpidan-1-methanol acetate (ester) is an alkaloidal compound identified in the PEE of S. tenerrimum in this study. This bioactive compound has been reported to have anti-inflammatory, anti-bacterial, anti-fungal, and anti-cancer properties (Al Rubaye et al., 2017).

Table 2 shows the results of the GC-MS analysis of the methanolic extracts of $S$. tenerrimum, and the structures of the compounds identified are presented in Figure 3. A steroidal compound cholest-5-en-3-ol, 24- propylidene-, (3á)- was detected in the ME of $S$. tenerrimum with the highest retention time of 59.50 minutes. Also, a similar compound has been reported in the ethanolic extract of Ipomoea staphylina Roem \& Schult (Padmashree et al., 2018). The ME of $S$. tenerrimum showed the presence of 1,2-benzenedicarboxylic acid, diisooctyl ester, which is also called diisooctyl phthalate, and phthalic acid. An earlier study suggested that 1,2-benzenedicarboxylic acid and diisooctyl ester, isolated and extracted in methanol from the unripe fruits of Nauclea latifolia, exhibited antibacterial properties (Padmashree et al., 2018); they were also reported to be present in Jania rubens, a red alga (Soad et al., 2016). Another study reported its antioxidant and anticholinesterase activities in the dichloromethane extract of Sargassum wightii (Syad et al., 2013).

The GC-MS results revealed the presence of different types of long-chain fatty acids, such as tetratetracontane and hexatriacontane in the ME of $S$. tenerrimum. A previous study suggested the presence of tetratetracontane and hexatriacontane in the diethyl ether and ethanolic extracts, respectively, of Sargassum fusiforme (El Shafay et al., 2016). Tetratetracontane was identified as one of the bioactive constituents in the hexane extract of the aerial parts of Quisqualis indica, and the extract was also demonstrated to have antibacterial activity (Agarwal et al., 2017). Hentriacontane, also called untriacontane, is a longchain alkane hydrocarbon that was previously reported in the hexane extract of $T$. ornate and exhibited larvicidal effects (Sowmiya et al., 2017). Kim et al. (2011) reported that hentriacontane from Oldenlandia diffusa exhibited anti-inflammatory, antioxidant, and anti-tumor activities. 1-Docosene and 1-nonadecene are alkenes that were identified in the ME of S. tenerrimum in this study. Recent reports show that the dichloromethane extract of the red seaweed Corallina officinalis contains 1-docosene and exhibits antibacterial properties (Sahar and Aida, 2018). Studies have suggested that the chloroform extract of $C$. racemose, a green alga, contains 1 -nonadecene that exhibits antioxidant, anti-inflammatory, and anti-cancer activities (Sivakumar and Balaraman, 2018). Interestingly, the compound 1-nonadecene was identified in the wastewater of a leather industry (Natarajan et al., 2013). 1-Hexadecanol, also called cetyl alcohol or palmityl alcohol, is a fatty acid that has a moderate retention time and is widely used in the cosmetic industry as a non-gelling thickening agent (Ribeiro et al., 2004). Recently, hexadecane was identified in seaweeds by Mohy El-Din and Alagawany (2019). In this study, 1,2-Benzenediol and were detected with the lowest retention times at 13.73 and 13.25 minutes, respectively, in the ME of $S$. tenerrimum. 1,2-Benzenediol, also known as pyrocatechol, and benzoic acid found in the methanolic extract and crude extract, respectively, of the red alga Rhodomela confervoides exhibited antibacterial properties (Nianjun et al., 2003). Benzoic acid was one of the bioactive constituents in Sargassum wightii (Balachandran et al., 2016); it has found use as a food preservative that inhibits macroautophagy (Park et al., 2001), and its derivatives showed antimicrobial effects against screened microorganisms (Hazan et al., 2004).

\subsection{FT-IR spectroscopy analysis}

The preliminary phytochemical investigation of the ME and PEE of Sargassum tenerrimum showed the presence

Table 2. Bioactive compounds of methanolic extracts of Sargassum tenerrimum identified through by GC-MS analysis.

\begin{tabular}{|c|c|c|c|c|c|}
\hline S.no & Bioactive compound & $\begin{array}{l}\text { Molecular } \\
\text { formula }\end{array}$ & $\begin{array}{c}\text { Retention } \\
\text { time } \\
\text { (Minutes) }\end{array}$ & $\begin{array}{l}\text { Molecular } \\
\text { weight }\end{array}$ & $\begin{array}{l}\text { Retention } \\
\text { Index }\end{array}$ \\
\hline 1 & $\begin{array}{l}\text { Cholest-5-en-3-ol, 24- propylidene-, } \\
\text { (3á)- }\end{array}$ & $\mathrm{C}_{30} \mathrm{H}_{50} \mathrm{O}$ & 59.50 & 426 & 2861 \\
\hline 2 & $\begin{array}{l}\text { 1,2-Benzenedicarboxylic acid, } \\
\text { diisooctyl ester }\end{array}$ & $\mathrm{C}_{24} \mathrm{H}_{38} \mathrm{O}_{4}$ & 45.78 & 390 & 2698 \\
\hline 3 & Tetratetracontane & $\mathrm{C}_{44} \mathrm{H}_{90}$ & 45.03 & 618 & Unconfirmed \\
\hline 4 & Hentriacontane & $\mathrm{C}_{31} \mathrm{H}_{64}$ & 42.98 & 436 & 3116 \\
\hline 5 & 1-Docosene & $\mathrm{C}_{22} \mathrm{H}_{44}$ & 32.35 & 308 & 2174 \\
\hline 6 & 1-Nonadecene & $\mathrm{C}_{19} \mathrm{H}_{38}$ & 28.33 & 266 & 1878 \\
\hline 7 & 1-Hexadecanol & $\mathrm{C}_{16} \mathrm{H}_{34} \mathrm{O}$ & 18.93 & 242 & 1854 \\
\hline 8 & 1,2-Benzenediol & $\mathrm{C}_{6} \mathrm{H}_{6} \mathrm{O}_{2}$ & 13.73 & 110 & 1189 \\
\hline 9 & Benzoic acid & $\mathrm{C}_{7} \mathrm{H}_{6} \mathrm{O}_{2}$ & 13.25 & 122 & 1156 \\
\hline
\end{tabular}




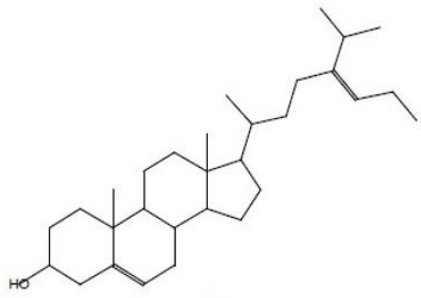

1

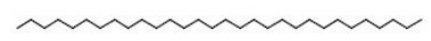

4

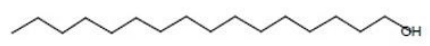

7<smiles>CC(C)CCCCCCCCC(C)c1ccccc1C(C)CCCCC(C)C</smiles>

2

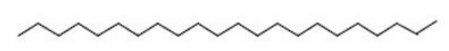

5

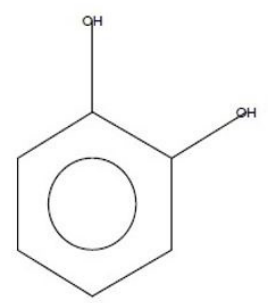

8
3
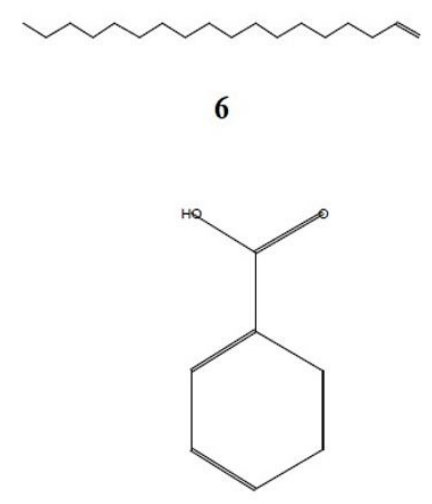

9

Figure 3. Bioactive compounds of methanolic extract of Sargassum tenerrimum identified through by GC-MS analysis (1) Cholest-5-en3-ol, 24- propylidene-, (3á)-, (2) 1,2-Benzenedicarboxylic acid, diisooctyl ester (3) Tetratetracontane (4) Hentriacontane (5) 1-Docosene (6) 1-Nonadecene (7) 1-Hexadecanol (8) 1,2-Benzenediol (9) Benzoic acid.

of polysaccharides, flavonoids, terpenoids, amino acids, proteins, phenolic compounds, and sterol alkaloids, as shown in Table 3. FT-IR predicted the prominent functional groups present in the extract. Characteristic peaks were observed at 3355, 2959, 2945, 2927, 2873, 2832, 2359, 2051, $1652,1451,1030,881$ and $739 \mathrm{~cm}^{-1}$ (Figures 4, 5). The broad peak conforming to $3355 \mathrm{~cm}^{-1}$ indicates the presence of polymeric hydroxyl groups in unsaturated fatty acids, steroids, saponins, flavonoids etc. The peaks corresponding to $2959,2945,2927,2873$, and $2832 \mathrm{~cm}^{-1}$ indicate symmetrical and asymmetrical C-H stretching in aliphatic compounds, polysaccharides, steroids, squalene, and tannins. The small peak at $2359 \mathrm{~cm}^{-1}$ corresponds to $\mathrm{S}-\mathrm{H}$ stretching vibration that indicates different amino acids and proteins. The characteristic peaks present at $2051 \mathrm{~cm}^{-1}$ are attributed to alkynes $(C \equiv C)$ and alkenes $(C=C)$ in ketones (Dovbeshko et al., 2000). The carbonyl stretching vibrations around $1652 \mathrm{~cm}^{-1}$ in the extract indicate the presence of aldehydes, ketones, acids, and esters (Zhou et al., 2010). A medium-intensity peak at $1451 \mathrm{~cm}^{-1}$ reveals the existence of asymmetric $\mathrm{CH}_{3}$ bending vibrations of the methyl groups of proteins (Nyquist, 2001).

The peak corresponding to $1030 \mathrm{~cm}^{-1}$ is characteristic of the $\mathrm{C}-\mathrm{O}$ stretching of glycogens. The peaks at $881 \mathrm{~cm}^{-1}$ and $739 \mathrm{~cm}^{-1}$ indicate the presence of $\mathrm{C}-\mathrm{H}$ out of plane bending and $\mathrm{C}-\mathrm{Cl}$ stretching of polysaccharides and halogenated compounds, respectively. The analysis of the algal extract through FT-IR showed the presence of prominent functional groups of the biologically active alcohols, acids, phenols, esters, ethers, and alkanes found. Antimicrobial activity has generally been attributed to long-chain unsaturated fatty acids (C16-C20), such as oleic, linoleic, and, palmitic acid, and saturated fatty acids, such as stearic and palmitic acid (Zheng et al., 2005).

\subsection{Antibacterial studies}

The results presented in Table 4 summarize the antibacterial effects of the PEE and ME of S. tenerrimum. The PEE of S. tenerrimum exhibited antibacterial activity due to the presence of hexadecenoic acid, methyl ester, 17-pentatriacontene, dasycarpidan-1-methanol, and acetate (ester). The ME of $S$. tenerrimum showed activity against the selected human pathogenic bacteria. The antibacterial activity of the ME of $S$. tenerrimum was due to the presence of 1,2-benzenedicarboxylic acid, diisooctyl ester, tetratetracontane, 1-docosene, 1,2-benzenediol and, benzoic acid. The ME showed better activity than the PEE against both, gram-positive and gram-negative bacteria. Although the extracts showed good activity against the screened organisms, their efficacy was significantly lower than that of the standard streptomycin disc ( $10 \mu \mathrm{g} /$ disc $)$. 
Table 3. Chemical composition of Sargassum tenerrimum as obtained from FTIR Spectroscopy of both the PEE and ME extracts.

\begin{tabular}{|c|c|c|c|c|}
\hline $\begin{array}{c}\text { Wave } \\
\text { number } \\
(\mathrm{cm}-1)\end{array}$ & $\begin{array}{l}\text { Intensity } \\
\text { Estimation }\end{array}$ & $\begin{array}{l}\text { Functional } \\
\text { group }\end{array}$ & $\begin{array}{c}\text { Type of } \\
\text { vibration }\end{array}$ & Possible Compounds \\
\hline 3355 & Weak & $\mathrm{O}-\mathrm{H}$ & Stretching & $\begin{array}{l}\text { Phenolic compounds, stigmasterol, 15-hydroxy progesterone, } \\
\text { fucosterol, polysaccharides, myristic acid, arachidonic acid, } \\
\text { flavanoids, saponins }\end{array}$ \\
\hline 2959 & Strong & $\mathrm{C}-\mathrm{H}$ & $\begin{array}{l}\text { Asymmetrical } \\
\text { Stretching }\end{array}$ & Aliphatic compounds, squalene, steroids, tannins \\
\hline 2945 & Strong & $\mathrm{C}-\mathrm{H}$ & $\begin{array}{l}\text { Symmetrical } \\
\text { Stretching }\end{array}$ & Aliphatic compounds, squalene, steroids \\
\hline 2927 & Strong & $\mathrm{CHO}$ & Stretching & Aliphatic compounds \\
\hline 2873 & Strong & $\begin{array}{c}\mathrm{CH}_{2} \text { str. } \\
\text { (Symmetrical) }\end{array}$ & Stretching & Carbohydrate, proteins \\
\hline 2832 & Strong & $\begin{array}{c}\mathrm{OCH}_{3} \text { str. } \\
\text { (Symmetrical) }\end{array}$ & Stretching & Aliphatic compounds \\
\hline 2359 & Weak & S-H & Stretching & Amino acids \\
\hline 2051 & Weak & $\begin{array}{c}\mathrm{C} \equiv \mathrm{C}, \mathrm{C}=\mathrm{C} \text { in } \\
\text { ketones }\end{array}$ & Stretching & Steroids, hydroxy progesterone \\
\hline 1652 & Strong & $\mathrm{C}=\mathrm{O}, \mathrm{N}-\mathrm{H}$ & $\begin{array}{l}\mathrm{C}=\mathrm{O} \\
\text { Stretching } \\
\text { NH bending }\end{array}$ & $\begin{array}{l}\text { Myristic acid, esters like methyl palmitate, methyl oleate, } \\
\text { aldehydes, aromatic ketones, myristic acid, arachidonic acid }\end{array}$ \\
\hline 1451 & Strong & $\mathrm{C}-\mathrm{H}$ & $\begin{array}{l}\text { Asymmetrical } \\
\text { bending }\end{array}$ & Proteins \\
\hline 1030 & Medium & $\mathrm{C}-\mathrm{O}$ & Stretching & Glycogens \\
\hline 881 & Medium & $\mathrm{C}-\mathrm{H}$ & $\begin{array}{l}\text { Out of plane } \\
\text { bending }\end{array}$ & Polysaccharides \\
\hline 739 & Strong & $\mathrm{C}-\mathrm{Cl}$ & Stretching & Halogenated compounds \\
\hline
\end{tabular}

Title: ${ }^{*}$ Tue Feb 04 11:49:37 2020 (GMT+03:00) S. tenerrimum_P. ether

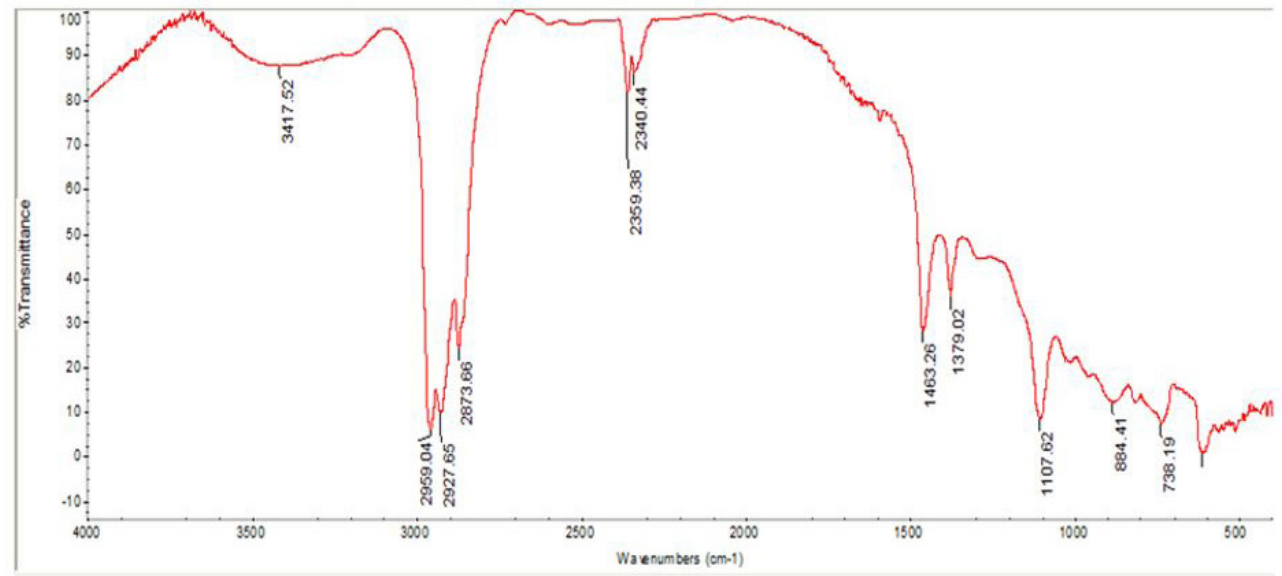

Expandedfingerprint region:

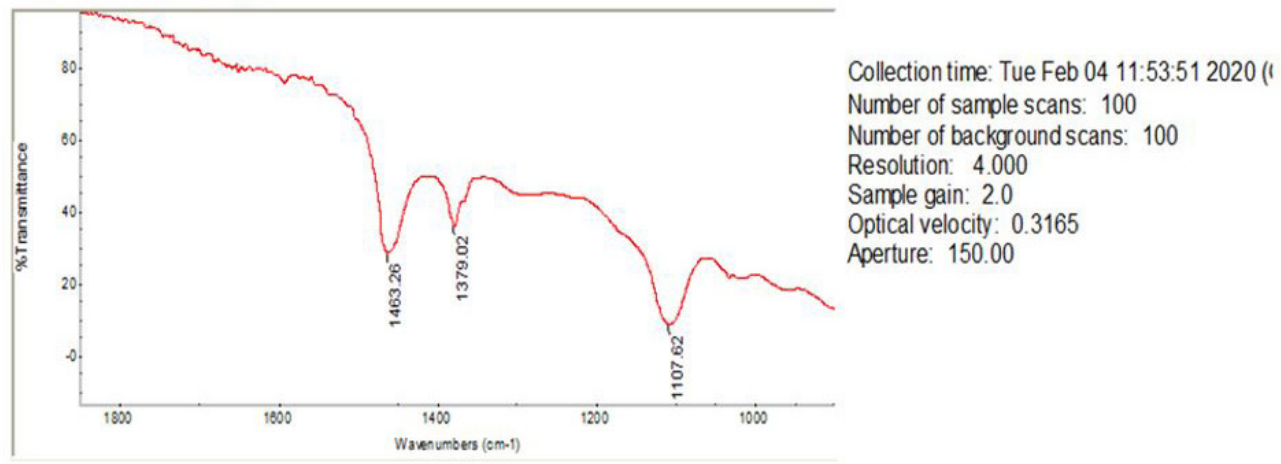

Figure 4. FT-IR spectral pattern of petroleum ether extract of Sargassum tenerrimum. 
Title: 'Tue Feb 04 11:40:13 2020 (GMT+03:00) S. tenerrimum_Methanol

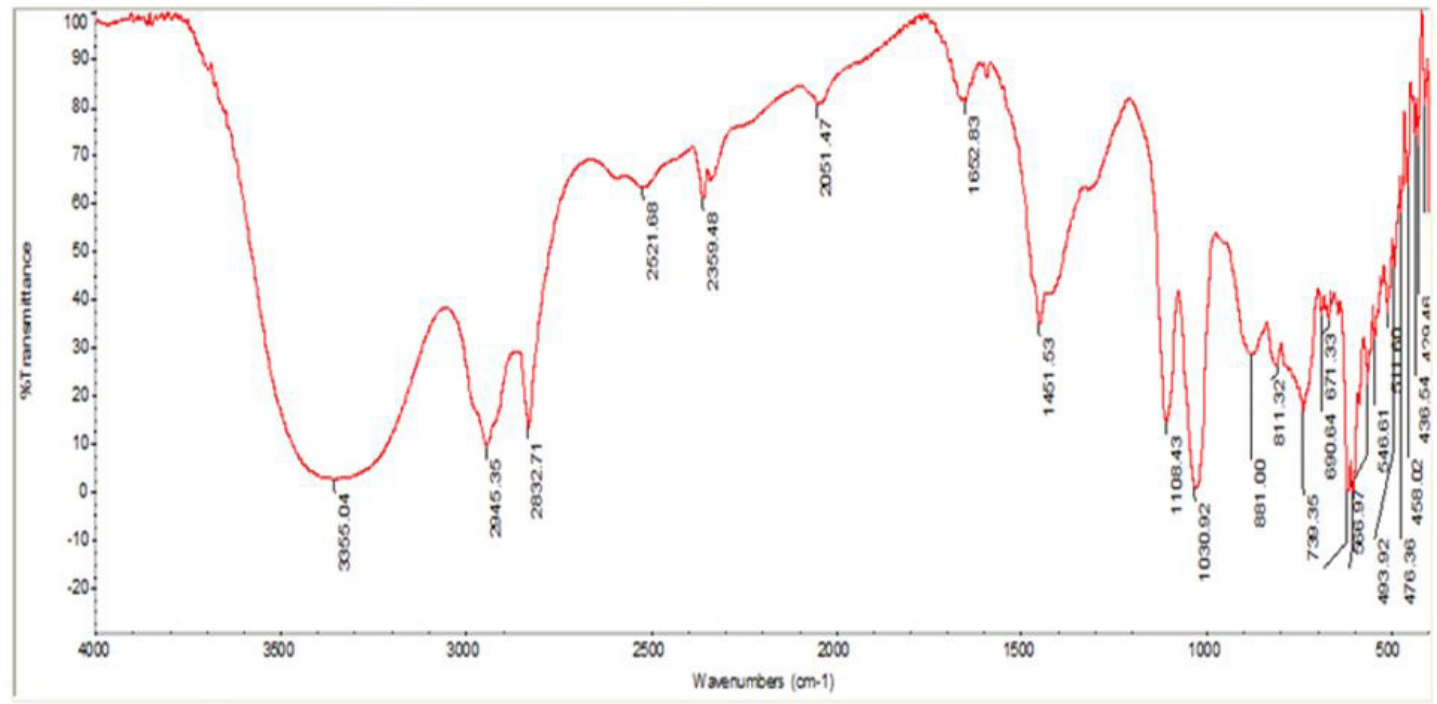

\section{Expanded fingerprint region:}

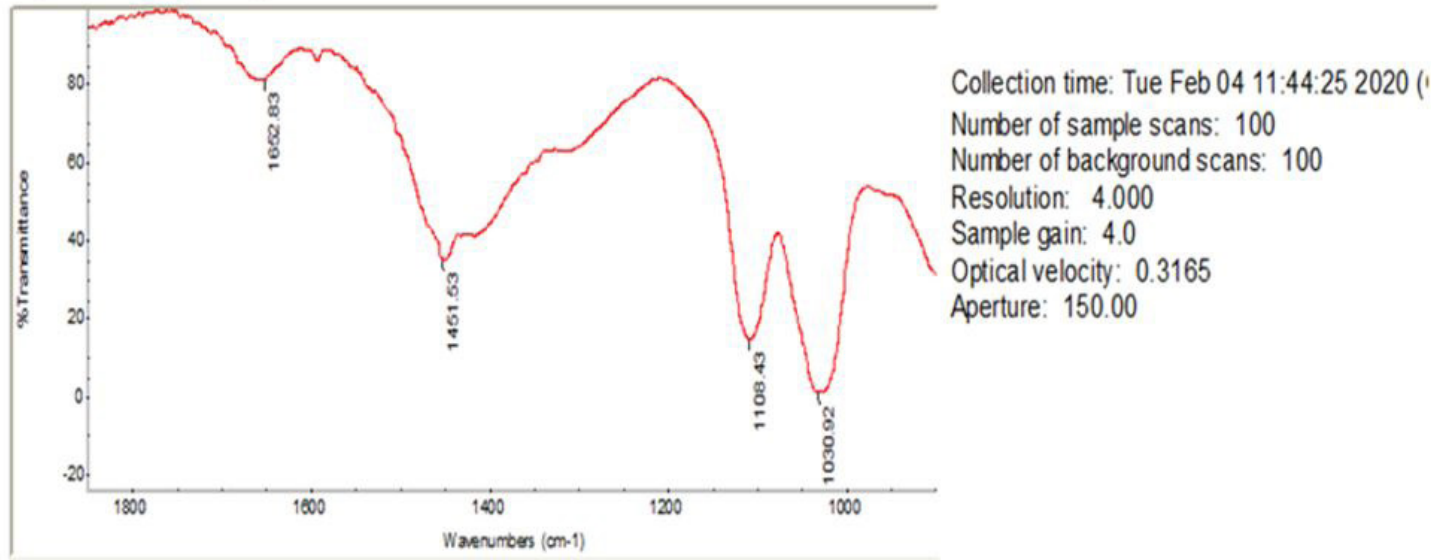

Figure 5. FT-IR spectral pattern of methanol extract of Sargassum tenerrimum.

Table 4. Antibacterial studies of the extracts of Sargassum tenerrimum.

\begin{tabular}{|c|c|c|c|c|}
\hline $\begin{array}{l}\text { Bacterial } \\
\text { Organisms }\end{array}$ & $\begin{array}{c}\text { Concentration of } \\
24 \text { h culture CFU / mL }\end{array}$ & Methanolic extract & $\begin{array}{c}\text { Petroleum ether } \\
\text { extract }\end{array}$ & $\begin{array}{c}\text { Streptomycin } \\
10 \mathrm{mcg} / \mathrm{disc}\end{array}$ \\
\hline Bacillus subtilis & $2 \times 10^{-4}$ & $19.3 \pm 1.2^{* *}$ & $16.6 \pm 2.5^{* *}$ & $26.24 \pm 1.6$ \\
\hline $\begin{array}{l}\text { Staphylococcus } \\
\text { aureus }\end{array}$ & $3 \times 10^{-5}$ & $20.3 \pm 1.5^{*}$ & $17.8 \pm 0.98^{* *}$ & $23.26 \pm 2.1$ \\
\hline $\begin{array}{l}\text { Streptococcus } \\
\text { pyogenes }\end{array}$ & $3 \times 10^{-4}$ & $11.8 \pm 1.3^{* *}$ & $8.3 \pm 0.6^{* *}$ & $22.6 \pm 1.3$ \\
\hline Escherichia coli & $2 \times 10^{-6}$ & $20.6 \pm 1.6^{* *}$ & $12.5 \pm 1.2^{* *}$ & $28.2 \pm 1.6$ \\
\hline $\begin{array}{l}\text { Pseudomonas } \\
\text { aeruginosa }\end{array}$ & $2 \times 10^{-3}$ & $17.3 \pm 2.3^{* *}$ & $14.3 \pm 1.6^{* *}$ & $25.3 \pm 1.3$ \\
\hline $\begin{array}{l}\text { Klebsiella } \\
\text { pneumonia }\end{array}$ & $2 \times 10^{-3}$ & $22.8 \pm 2.4^{*}$ & $19.5 \pm 1.04^{* *}$ & $26.6 \pm 1.2$ \\
\hline
\end{tabular}

Each value is the mean of 6 batches with standard deviation by performing Dunnett multiple comparison test (Sample vs Standard), (post hoc test); ${ }^{* *} \mathrm{P}<0.01$ (99\% confidence interval) is very extremely significant and ${ }^{*} \mathrm{P}<0.05$ (95\% confidence interval) is significantly lesser when compared to standard streptomycin disc. CFU: Colony forming unit 


\section{Conclusion}

The present study has documented the scientific evidence of the antibacterial properties of the petroleum ether (PEE) and methanolic (ME) extracts of S. tenerrimum, a brown alga found in the Red Sea, Jazan Province, Kingdom of Saudi Arabia. Bioactive molecules varied widely in their molecular structures in both ME and PEE. The ME of $S$. tenerrimum exhibited better antibacterial activity than the PEE. The results obtained in this study indicate that anti-bacterial active principles can be isolated from $S$. tenerrimum; they would be beneficial in the development of new antibacterial agents in the future.

\section{References}

AGARWAL, A., PRAJAPATI, R., RAZA, S.K. and THAKUR, L.K., 2017. GC-MS analysis and antibacterial activity of aerial parts of Quisqualis indica plant extracts. Indian Journal of Pharmaceutical Education and Research, vol. 51, no. 2, pp. 329-336. http://dx.doi. org/10.5530/ijper.51.2.39.

AL-RUBAYE, A.F., KAIZAL, A.F. and HAMEED, I.H, 2017. Phytochemical screening of methanolic leaves extract of Malva Sylvestris. International Journal of Pharmacognosy and Phytochemical Research, vol. 9, no. 4, pp. 537-552. http://dx.doi.org/10.25258/ phyto.v9i4.8127.

ARDREY, R.E. and MOFFAT, A.C., 1981. Gas-liquid chromatographic retention indices of 1318 substances of toxicological interest on SE-30 or OV-1 stationary phase. Journal of Chromatography, vol. 220, no. 3, pp. 195-252. http://dx.doi.org/10.1016/S00219673(00)81925-1. PMid:7035473.

ASTUDILLO, A.M., MEANA, C., GUIJAS, C., PEREIRA, L., LEBRERO, P., BALBOA, M.A. and BALSINDE, J., 2018. Occurrence and biological activity of palmitoleic acid isomers in phagocytic cells. Journal of Lipid Research, vol. 59, no. 2, pp. 237-249. http://dx.doi. org/10.1194/jlr.M079145. PMid:29167413.

BAKAR, K., MOHAMAD, H., LATIP, J., TAN HOCK, S. and MING, H., 2017. Fatty acids compositions of Sargassum granuliferum and Dictyota dichotoma and their anti-fouling activities. Journal of Sustainability Science and Management, vol. 12, no. 2, pp. 8-16.

BALACHANDRAN, P., VISWESWARAN, P. and AJAY KUMAR, T.V., 2016. Isolation of compounds from Sargassum wightii by GCMS and the molecular docking against anti-inflammatory marker COX2. International Letters of Chemistry. Physics and Astronomy, vol. 63, pp. 1-12. http://dx.doi.org/10.18052/www. scipress.com/ILCPA.63.1.

BHUTIYA, P.L., MAHAJAN, M.S., ABDUL RASHEED, M., PANDEY, M., ZAHEER HASAN, S. and MISRA, N., 2018. Zinc oxide nanorod clusters deposited seaweed cellulose sheet for antimicrobial activity. International Journal of Biological Macromolecules, vol. 112, pp. 1264-1271. http://dx.doi. org/10.1016/j.ijbiomac.2018.02.108. PMid:29458103.

CAPPUCCINO, J.G. and SHERMAN, N., 2014. Microbiology - a laboratory manual. USA: Pearson Education, Inc.

CHUKWUNONYE, M.O., KELECHI, I.N. and MARYCOLETTE, N.E., 2015. The chemical constituents and bioactivity of the seed (Fruit) extracts of Buchholzia Coriacea Engler (Capparaceae). Journal of Applied Science E Environmental Management, vol. 19, no. 4, pp. 795-801. http://dx.doi.org/10.4314/jasem.v19i4.29.

DINESH, K.G., KARTHIK, M. and RAJAKUMAR, R., 2018. GC-MS analysis of bioactive compounds from ethanolic leaves extract of Eichhornia crassipes (Mart) Solms. and their pharmacological activities. The Pharma Innovation Journal, vol. 7, no. 8, pp. 459-462.

DOVBESHKO, G.I., GRIDINA, N.Y., KRUGLOVA, E.B. and PASHCHUK, O.P., 2000. FT-IR spectroscopy studies of nucleic acid damage. Talanta, vol. 53, no. 1, pp. 233-246. http://dx.doi.org/10.1016/ S0039-9140(00)00462-8. PMid:18968108.

ELSHAFAY, S.M., ALI, S.S. and EL-SHEEKH, M.M., 2016. Antimicrobial activity of some seaweeds speciesfrom Red sea, against multidrug resistant bacteria. The Egypt Journal of Aquatic Research, vol. 42, no. 1, pp. 65-74. http://dx.doi.org/10.1016/j. ejar.2015.11.006.

GIUSEPPE, D.G., ELENA, F. and ROBERTO, B., 2006. Vaccines with the MF59 adjuvant do not stimulate antibody responses against squalene. Clinical and Vaccine Immunology, vol. 13, no. 9, pp. 1110-1113. http://dx.doi.org/10.1128/CVI.00191-06.

HAZAN, R., LEVINE, A. and ABELIOVICH, H., 2004. Benzoic acid, a weak organic acid food preservative, exerts specific effects on intracellular membrane trafficking pathways in Saccharomyces cerevisiae. Applied and Environmental Microbiology, vol. 70, no. 8, pp. 4449-4457. http://dx.doi.org/10.1128/AEM.70.8.44494457.2004. PMid:15294772.

HUANG, Z.R., LIN, Y.K. and FANG, J.Y., 2009. Biological and pharmacological activities of squalene and related compounds: potential uses in cosmetic dermatology. Molecules, vol. 14, no. 1, pp. 540-554. http://dx.doi.org/10.3390/molecules 14010540.

JOHN, C., CHRISTENSON, E. and KORGENSKI, K., 2018. Laboratory diagnosis of infection due to bacteria, fungi, parasites, and rickettsiae. In: S.S. LONG, L. K. PICKERING and C. G. PROBER, editors. Principles and practice of paediatric infectious diseases. 5th ed. USA: Elsevier Publications, $286 \mathrm{p}$.

KIM, S.J., CHUNG, W.S., KIM, S.S., KO, S.G. and UM, J.Y., 2011. Antiinflammatory Effect of Oldenlandia diffusa and its Constituent, Hentriacontane, through Suppression of Caspase-1 Activation in mouse peritoneal macrophages. Phytotherapy Research, vol. 25, no. 10, pp. 1537-1546. http://dx.doi.org/10.1002/ptr.3443. PMid:21394806.

KUMAR, P., SINGARAVELU, S.S., LAKSHMI, P., PREM KUMAR, K., GANESH KUMAR, R.S. and GOVINDARAJU, M., 2012. Synthesis of silver nanoparticles from Sargassum tenerrimum and screening phytochemicals for its anti-bacterial activity. Nano Biomedicine and Engineering, vol. 4, no. 4, pp. 12-16. http:// dx.doi.org/10.5101/nbe.v4i1.p12-16.

LOZANO-GRANDE, M.A., GORINSTEIN, S., ESPITIA-RANGEL, E., DÁVILA-ORTIZ, G. and MARTÍNEZ-AYALA, A.L., 2018. Plant sources, extraction methods, and uses of squalene. International Journal of Agronomy, vol. 2018, pp. 1-13. http://dx.doi. org/10.1155/2018/1829160.

MARIA, J.P., ELENA, F. and HERMINIA, D., 2016. Anti-microbial action of compounds from marine seaweed. Marine Drugs, vol. 14, no. 52, pp. 1-38. http://dx.doi.org/10.3390/md14030052.

MEGHA, B., NIRMAL KUMAR, J.I. and RITA, N.K., 2016. Bioactive compounds and antifungal activity of three different seaweed species Ulva lactuca, Sargassum tenerrimum and Laurencia btuse collected from Okha coast, Western India. Journal of Coastal Life Medicine, vol. 4, no. 4, pp. 284-289. http://dx.doi. org/10.12980/jclm.4.2016J5-185.

MOHY EL-DIN, S.M. and ALAGAWANY, N.I., 2019. Phytochemical constituents and anticoagulation property of marine algae Gelidium crinale, Sargassum hornschuchii and Ulva linza. Thalassas, vol. 35, no. 2, pp. 381-397. http://dx.doi.org/10.1007/ s41208-019-00142-6.

MONI, S.S., ALAM, M.F., MAKEEN, H.A., ALHAZMI, H.A., SULTAN, M., SIDDIQUI, R., JABEEN, A., SANOBAR, S., ALAM, M.S., 
REHMAN, Z.U., ELMOBARK, M.E., MADKHALI, O., HAQUE, A., and ALBRATTY, M., 2019. Solvent extraction, spectral analysis and antibacterial activity of the bioactive crystals of Sargassum aquifolium (Turner) C Agardh from Red Sea. Natural Product Research. vol. 35, no. 8, pp. 1379-1383. http://dx.doi.org/10.10 80/14786419.2019.1645659.

MONI, S.S., ALAM, M.F., SAFHI, M.M., JABEEN, A., SANOBAR, S., SIDDIQUI, R. and MOOCHIKKAL, R., 2018. Potency of nanoantibacterial formulation from Sargassum binderi against selected human pathogenic bacteria. Brazilian Journal of Pharmaceutical Sciences, vol. 54, no. 4, pp. 1-9. http://dx.doi. org/10.1590/s2175-97902018000417811.

NAMVAR, F., BAHARARA, J. and MAHDI, A.A., 2014. Antioxidant and anticancer activities of selected Persian Gulf algae. Indian Journal of Clinical Biochemistry, vol. 29, no. 1, pp. 13-20. http:// dx.doi.org/10.1007/s12291-013-0313-4. PMid:24478544.

NATARAJAN, T.S., NATARAJAN, K., BAJAJ, H. and TAYADE, R.J., 2013. Study on identification of leather industry wastewater constituents and its photocatalytic treatment. International Journal of Environmental Science and Technology, vol. 10, no. 4 pp. 855-864. http://dx.doi.org/10.1007/s13762-013-0200-9.

NIANJUN, X.U., XIAO, F., XIAOJUN, Y., LI, X., NIU, R. and TSENG, C.K., 2003. Antibacterial bromophenols from the marine red alga Rhodomela confervoides. Phytochemistry, vol. 62, no. 8, pp. 1221-1224. http://dx.doi.org/10.1016/S0031-9422(03)00004-9. PMid: 12648540 .

NYQUIST, N.A., 2001. Interpreting infrared, raman and nuclear magnetic resonance spectra. London: Academic Press.

PADMASHREE, M.S., ROOPA, B., ASHWATHANARAYANA, R. and NAIKA, R., 2018. Antibacterial properties of Ipomoea staphylina Roem \& Schult. plant extracts with comparing its preliminary qualitative phytochemical and quantitative GC-MS analysis. Tropical Plant Research, vol. 5, no. 3, pp. 349-369. http://dx.doi. org/10.22271/tpr.2018.v5.i3.044.

PARK, E.-S., MOON, W.-S., SONG, M.-J., KIM, M.-N., CHUNG, K.H. and YOON, J.-S., 2001. Antimicrobial activity of phenol and benzoic acid derivatives. International Biodeterioration E Biodegradation, vol. 47, no. 4, pp. 209-214. http://dx.doi. org/10.1016/S0964-8305(01)00058-0.

PAUDEL, M.R., CHAND, M.B., PANT, B. and PANT, B., 2018. Antioxidant and cytotoxic activities of Dendrobium moniliforme extracts and the detection of related compounds by GC-MS. BMC Complementary and Alternative Medicine, vol. 18, no. 1, pp. 134 http://dx.doi.org/10.1186/s12906-018-2197-6. PMid:29685150.

PELGRIFT, R.Y. and FRIEDMAN, A.J., 2013. Nanotechnology as a therapeutic tool to combat microbial resistance. Advanced Drug Delivery Reviews, vol. 65, no. 13-14, pp. 1803-1815. http://dx.doi. org/10.1016/j.addr.2013.07.011. PMid:23892192.

PERMEH, P., SAEIDNIA, S., MASHINCHIAN-MORADI, A. and GOHARI, A.R., 2012. Sterols from Sargassum oligocystum, a brown alga from the Persian Gulf, and their bioactivity. Natural Product Research, vol. 26, no. 8, pp. 774-777. https://dx.doi.org/10.108 0/14786419.2010.548812.
RIBEIRO, H.M., MORAIS, J.A. and ECCLESTON, G.M., 2004. Structure and rheology of semisolid o/w creams containing cetyl alcohol/ non ionic surfactant mixed emulsifier and different polymers. International Journal of Cosmetic Science, vol. 26, no. 2, pp. 47-59. http://dx.doi.org/10.1111/j.0412-5463.2004.00190.x. PMid: 18494913.

RILEY, M.A., ROBINSON, S.M., ROY, C.M., DENNIS, M., LIU, V. and DORIT, R.L., 2012. Resistance is futile: the bacteriocin model for addressing the antibiotic resistance challenge. Biochemical Society Transactions, vol. 40, no. 6, pp. 1438-1442. http://dx.doi. org/10.1042/BST20120179. PMid:23176495.

SAHAR, W.M.H. and AIDA, H.S., 2018. GC/MS identification and applications of bioactive seaweed extracts from Mediterranean coast of Egypt. The Egypt Journal of Aquatic Research, vol. 22, no. 5, pp. 1-21. http://dx.doi.org/10.21608/ejabf.2018.17952.

SALEHI, B., SHARIFI-RAD, J., SECA, A.M.L., PINTO, D.C.G.A., MICHALAK, I., TRINCONE, A., MISHRA, A.P., NIGAM, M., ZAM, W. and MARTINS, N., 2019. Current trends on seaweeds: looking at chemical composition, phytopharmacology, and cosmetic applications. Molecules (Basel, Switzerland), vol. 24, no. 22, pp. 4182. http://dx.doi.org/10.3390/molecules24224182. PMid:31752200.

SIVAKUMAR, D. and BALARAMAN, D., 2018. Phytochemical profiling and GC-MS analysis of Caulerpa racemose. Research Journal of Pharmaceutical, Biological and Chemical Sciences, vol. 4, no. 5, pp. 155-165. http://dx.doi.org/10.26479/2018.0405.12.

SOAD, M., EL-DIN, M. and AMANI, M.D., 2016. Bioactivity and phytochemical constituents of marine red seaweeds (Jania rubens, Corallina mediterranea and Pterocladia capillacea). Journal of Taibah University for Science, vol. 10, no. 4, pp. 471484. http://dx.doi.org/10.1016/j.jtusci.2015.06.004.

SOWMIYA, R., BALASUBRAMANI, G., DEEPAK, P., AISWARYA, D., RAVIKUMAR, S. and PERUMAL, P., 2017. Characterization and screening of in vitro antimalarial and larvicidal activities of selected seaweeds from southeast coast of India against Plasmodium falciparum and Anopheles stephensi. Journal of Coastal Life Medicine, vol. 5, no. 6, pp. 242-248. http://dx.doi. org/10.12980/jclm.5.2017J7-35.

SYAD, A.N., SHUNMUGIAH, K.P. and KASI, P.D., 2013. Antioxidant and anti-cholinesterase activity of Sargassum wightii. Pharmaceutical Biology, vol. 51, no. 11, pp. 1401-1410. http://dx.doi.org/10.310 9/13880209.2013.793721. PMid:23862648.

ZHENG, H.F., LI, X.L., JIN, Z.Y., SUN, J.B., LI, Z.L. and XU, W.X., 2005. Effects of unsaturated fatty acids on calcium-activated potassium current in gastric myocytes of guinea pigs. World Journal of Gastroenterology, vol. 11, no. 5, pp. 672-675. http:// dx.doi.org/10.3748/wjg.v11.i5.672. PMid:15655819.

ZHOU, D., ZHANG, L., ZHANG, S., FU, H. and CHEN, J., 2010. Hydrothermal liquefaction of macroalgae Enteromorpha prolifera to bio-oil. Energy \& Fuels, vol. 24, no. 7, pp. 4054-4061. http://dx.doi.org/10.1021/ef100151h. 